\title{
INCOME TAX TREATMENT OF SHIFTS IN PARTNERSHIP PROFIT AND LOSS INTERESTS
}

Limited partnerships have become increasingly common investment vehicles for high-income taxpayers because of the tax advantages of the pass-through concept of partnerships. ${ }^{1}$ Limited partnerships are entities that report profits and losses on a partnership tax return, but the individual partners bear the tax consequences. ${ }^{2}$ Usually, several limited partners provide the bulk of the start-up funds for a limited partnership, while one or more general partners, who make less significant contributions of property, assume responsibility for the day-to-day operations and inanagement of the partnership. The Internal Revenue Code (Code) allows a variety of methods for structuring such partnerships, ${ }^{3}$ depending on the needs of the individual partners. With one frequently used method known as the "flip-flop," partners allocate in advance their profits and losses for a predetermined period of time; only after that time do the percentage allocations among partners change. ${ }^{5}$

The following hypothetical transaction illustrates a flip-flop in a limited partnership, coinposed of two limited partners, $A$ and $B$, and a general partner, $C$. Assume the partnership's purpose is to invest in real estate and that $A$ and $B$ contribute ninety percent of the partnership's start-up capital of $\$ 100,000$; general partner $C$ contributes the remaining ten percent. In order that the limited partners may take

1. As Arthur Willis has stated, "[t]he limited partnership became considerably more popular when taxpayers and their advisers recognized the tax advantages of the pass-through concept of partnerships." 3 A. Willis, J. Pennell \& P. Postlewaite, Partnership Taxation app. B-1 (3d ed. 1981).

2. For a brief background discussion of the development of the partnership concept, see $i d$. at $\S 1.04$. Under Subchapter $\mathrm{K}$ of the Internal Revenue Code, partners can allocate gain, loss, deductions, income, or credits among themselves as they see fit, without regard for their capital contributions. 26 U.S.C. $\$ 704(a)$ (1982).

3. See, e.g., Weidner, Passing Depreciation to Investor-Partners, 25 S.C.L. REv. 215, 220 (1973) (explanation of different methods of defining partners' rights); Westin, The Hazy Boundary Between Partnership Allocations and Distributions, 9 J. REAL EST. TAX'N 22, 22-23 (1981) (profits, losses, and cash distributions may be shared in accordance with partners' capital contributions, or capital partners may recoup their capital contributions before general partners begin drawing profits; alternativcly, partners may provide for distributions that vary according to the ainount and duration of the capital partners' imvestments).

4. See Seago \& Horvitz, Some Subtle Effects of the Partnership Constructive Distribution Rules, 58 TAXES 97, 99 (1980).

5. See 1 A. Willis, J. Pennel \& P. Postlewaite, supra note 1 , at $\S 46.01$. 
advantage of the substantial losses that they expect during the initial years of the venture, ${ }^{6}$ the partners agree to allocate profits and losses for the first five years ${ }^{7}$ in the same ratio as the partners' contributions to start-up capital: ninety percent to ten percent. At the end of five years the partners agree to change the allocation of profits and losses to refiect the anticipated profits from the venture, so that $A$ and $B$ will receive fifty percent of the profits and losses, and $C$ will receive the other fifty percent.

When potential investors consider the tax consequences of such a fiip-fiop arrangement, the question arises whether such a shift in allocation of profits and losses constitutes a sale or exchange of a partnership interest under section 741 of the Internal Revenue Code, ${ }^{8}$ or, alternatively, whether it amounts to a constructive distribution of cash under section 752.9 The courts have not yet decided this question; ${ }^{10}$ indeed, there is a dearth of case law discussmg flip-flops in any context. ${ }^{11}$ Commentators, however, have uniformly concluded that fiip-flops do constitute taxable events. For example, the authors of one treatise suggest that:

[One] situation in which a partner may receive a money distribution in excess of the basis of his interest occurs when the partner's share of partnership liabilities is reduced, giving rise to a $\$ 752(\mathrm{~b})$ constructive cash distribution. For example, if the partnership's basis in its assets is less than the outstanding balance of the partnership's nonrecourse indebtedness, as is often the case in tax-shelter partnerships, a shift in the ratio in which the partners share profits . . . may trigger cash distributions to the partners whose profits interests are reduced in excess of their basis in their partnership interests. ${ }^{12}$

6. Accelerated depreciation is allowed for real property, 26 U.S.C. \& 168(b)(2) (1982). Subsequent citations to the Internal Revenue Code of 1954, codified at title 26 of U.S. Code, will be in the form "I.R.C."

7. Alternatively, limited partnerships sometimes provide that the flip-flop will take place after the limited partners' capital contributions have been recouped from partnership profits. See, e.g., Westin, supra note 3, at 26.

8. 1.R.C. $\$ 741$ (1982) provides for recognition of gain to a partner upon sale or exchange of a partnership interest. See infra text accompanying note 16.

9. I.R.C. \$752(b) (1982) provides that a reduction in a partner's share of partnership liabilities will be treated as a constructive distribution of cash to the partner. See infra text accompanying note 24 .

10. 1 A. Willis, J. Pennell \& P. Postlewalte, supra note 1 , at $\$ 46.03$.

11. One exception is Hamilton v. Uunted States, 82-2 U.S. Tax Cas. (CCH) ๆ 9546 (Ct. Cl. 1982) (partner's "net profits interest" guaranteed by provision in partnership agreement that acceleration of shift to more favorable profit/loss share for general partners could be brought about by payment to limited partners of specified portion of limited partners' unrecovered capital contributions, held to reflect economic reality and not to constitute a loan or transfer of imterest).

12. W. McKee, W. Nelson \& R. Whitmire, Federal Taxation of Partnerships and Partners, ๆ 19.03[1] (1977); see also 1 A. Willis, J. Pennell \& P. Postlewaite, supra note 1, at $\S 46.02$. 
This note analyzes the tax consequences of flip-flops in a limited partnership from three distinct viewpoints, examining whether any analysis can justify nonrecognition. The note first considers the possibility of either sale or exchange treatment or constructive distribution treatment of flip-flops. ${ }^{13}$ Then, it discusses whether partners' capital interests are relevant to deciding wliether a taxable event has occurred. ${ }^{14}$ Finally, it looks at the question of whether partners obtain economic gain at the time of a shift in profit and loss interests. ${ }^{15}$ The note concludes that because none of these inethods of analyzing flipflops justify nonrecognition, flip-fiops are taxable events under section 752.

\section{The Language of the Internal Revenue Code and REgULATIONS}

\section{A. Section 741: Sale or Exchange.}

Section 741 of the Interual Revenue Code deals with sales and exchanges of partnership interests:

In the case of a sale or exchange of an interest in a partnership, gain or loss shall be recognized to the transferor partner. Such gain or loss shall be considered as gain or loss from the sale or exchange of a capital asset, except as otherwise provided in section $751 \ldots .16$

The Supreme Court has held that when the Internal Revenue Code uses the words "sale" and "exchange" these words should be understood in the ordinary sense. ${ }^{17}$ Thus, the Court has held that when a partnership receives insurance proceeds no sale or exchange occurs under the Code because consideration is lacking. ${ }^{18}$ Similarly, the Tax Court has held that when a partner withdraws from a law firm without receiving any compensation for the partnership interest that has reverted to the firm, a forfeiture lias occurred rather than a sale or exchange. ${ }^{19}$ These holdings indicate that for a sale or exchange to occur under the Code, a taxpayer's interest in some asset inust terminate and the taxpayer must receive some econoumic beneflt in exchange for the asset.

13. See infra notes $16-39$ and accompanying text.

14. See infra notes $40-53$ and accompanying text.

15. See infra notes 54-71 and accompanying text.

16. I.R.C. $\$ 741$ (1982).

17. Helvering v. William Flaccus Oak Leather Co., 313 U.S. 247, 249 (1941) (insurance procceds for fire damage held not a sale or exchange); see also Hale v. Commissioner, 32 B.T.A. 356 (1935), affd, 85 F.2d 819, 822 (D.C. Cir. 1936).

18. Helvering v. Flaccus Oak Leather Co., 313 U.S. 247, 249 (1941).

19. Palmer Hutcheson v. Colnmissioner, 27 T.C. 14 (1951); Gannon v. Commissioner, 16 T.C. 1134,1139 (1951). 
Section 741's sale or exchange provision may apply to flip-fiops if a partner's surrender of a certain percentage of his partnership interest constitutes a termination of some interest. The change in the partner's profit and loss interest that occurs at the time of the flip-flop arguably relieves him of a corresponding portion of the partnership's liabilities, thereby providing the requisite economic benefit to characterize the event as a sale or exchange.

This argument, however, fails to take account of several characteristics of the flip-flop. The limited partner whose profit and loss interest decreases neither receives ${ }^{20}$ nor disposes ${ }^{21}$ of anything of value. The limited partners continue to have an imterest in the partnership after the fiip-flop. The only difference in the partners' interests before and after the flip-flop is the change in his proflt and loss sharing ratios. The prearranged shift in profit and loss sharing inerely results in a revised schedule governing allocation of future income; no distribution or transfer of currently held assets takes place. In this sense, flip-flops are similar to forfeitures: There is no surrender of a partnership interest for valuable consideration. ${ }^{22}$ Thus, the sale-or-exchange language of section 741 probably does not generate tax hability for hinited partners who engage in a flip-flop. ${ }^{23}$

\section{B. Section 752: Constructive Distributions.}

Altlough flip-flops do not seem to fall within section 741, they inay come witlim the ainbit of section 752 . That section provides:

(b) Decrease in partner's liabilities-Any decrease in a partner's sliare of the liabilities of a partnership, or any decrease in a partner's individual liabilities by reason of the assumption by the partnership

20. To the extent that a shift in profit and loss sharing can trigger a concomitant shift in a partner's share of partnership habilities, the tax consequences are properly considered under a constructive distribution analysis. See infra notes 24-39 and accompanying text.

21. A limited partner might lose the right to future income or deductions, but sucl a right is imtangible and cannot be valued.

22. Cf. supra text accoinpanying note 19 (terinination of an interest according to prearranged partnership agreement is not a sale or exchange).

23. Admittedly, not every instance of a sale or exchange consists of a simple transfer between two individuals of a partnership interest for cash. Courts have found, for example, that a sale or exchange occurred in transactions that did not involve any casl payments when the transactions included the receipt of some noncash interest. See, e.g., Robinson v. Elliot, 262 F.2d 383 (9th Cir. 1958) (agreement that included 10-year lease witl option to purchase, where nounimal lessee was responsible for all burdens of ownership, held to be a sale); Downer v. Commissioner, 48 T.C. 86 (1967) (transfer of 100,000 shares of stock by employer to employee, where latter thereupon agreed to continue employinent, held to be a sale or exchange). Similarly, a court has found that circuitous transfers aimed at disguising the form of a transaction involve a sale or exchange when a transfer of interests occurs. See Crenshaw v. United States, 450 F.2d 472 (5tl Cir. 1971). Flipflops do not fit within either of these categories, however. 
of such liabilities, sliall be considered as a distribution of money to the partner by the partnership. ${ }^{24}$

Section 752(b) recognizes a constructive distribution if the decrease in profit and loss sharing is accompanied by a decrease in the affected partner's share of partnership habilities. Such a corresponding decrease seems inandated by Treasury Regulation 1.752-1(e), which states: "A partner's share of partnership hiabilities shall be determined in accordance with his ratio for sharing losses under the partnership agreement."2s In other words, the reduction in partnership losses that occurs as part of the flip-flop may bring about a reduction in a partner's share of partnership liabilities by operation of Treasury Regulation 1.752-1(b). The Code would treat this reduction as a constructive distribution of cash, which is taxed under section 752(b)'s treatment of a "[d]ecrease in partner's habilities." 26 This brief discussion would seein to leave little doubt that flip-flops are taxable events under section 752; no court, however, has decided whether a decrease in profit and loss sharing triggers a section 752(b) distribution, ${ }^{27}$ although some commentators have suggested that it does. ${ }^{28}$

Despite the preceding analysis, it is possible to argue that section 752 does not apply to flip-flops. Recall the hypothetical partnership described above. ${ }^{29}$ Assume that after the partners contributed $\$ 100,000$ in start-up capital, they borrowed $\$ 400,000$ on a nonrecourse note. Limited partners $A$ and $B$, with equal profit and loss sharing interests of forty-five percent, can each include $\$ 180,000$ in the basis of their partnership interests, in addition to the $\$ 45,000$ start-up capital that each contributed. Assume the venture generated substantial depreciation deductions in its first few operating years, ${ }^{30}$ so that after five years, at which point the agreement states that the shift in profit and loss sharing is to take place, the partnership has generated $\$ 350,000$ in losses. The financial accounting for both $A$ and $B$ would be as follows:

24. I.R.C. \& 752(b) (1982).

25. Treas. Reg. $\S 1.752-1$ (e) (1983); see infra note 40 and accompanying text.

26. I.R.C. \& 752(b) (1982) (introductory language).

27. See 1 A. Willis, J. Pennell \& P. Postlewaite, supra note 1 , at $\$ 46.03$.

28. See, e.g., id; Seago \& Horvitz, supra note 4, at 99 ("A constructive distribution to the limited partners occurs when the profit and loss ratios change.").

29. See supra text accompanying notes 6-7.

30. Id. 


\section{Table I}

Capital contribution

Share of partnership liabilities

(nonrecourse mortgage)

Share of partnership losses

$(45 \%$ of $\$ 350,000)$

Adjusted basis in partnership interest at end of five years
$\$ 45,000$

180,000

$(157,500)$

67,500

The argument for construing the shift in profit and loss sharing as a constructive distribution of cash under section 752(b) is that after the shift, a partner's share of the partnership's liabilities must also be decreased, requiring an adjustment to basis. ${ }^{31}$ That is, the reduction in hability is viewed not as a sale or exchange, but rather as a distribution of cash that must be offset agamst the limited partner's basis in his partnership interest. Under a constructive distribution theory, therefore, gain is realized to the limited partner. The financial analysis would contmue for the limited partners as follows:

\section{Table II}

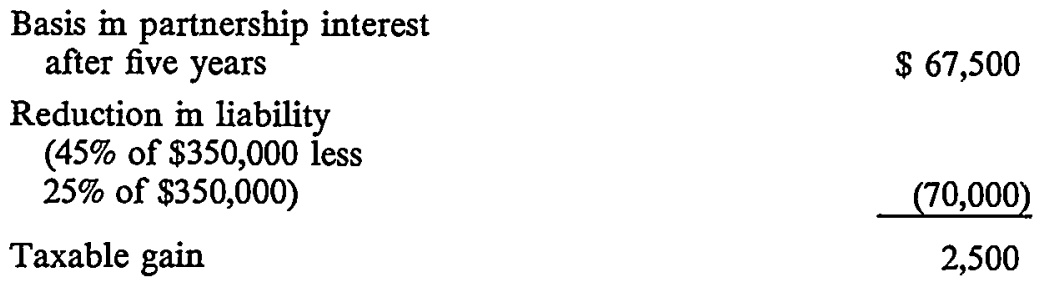

This analysis may, however, be challenged by examining the Treasury Regulations under section 752. Treasury Regulation 1.7521(b)(1) states in part that "[w]here the habilities of a partnership are decreased, and each partner's share of such liabilities is thereby decreased, the amount of the decrease shall be treated as a distribution of money to the partner by the partnership."32 This language could be interpreted to suggest that apphication of section 752 is contingent on both a reduction in a partner's hability and a decrease in the partnership's habilities, at least in cases covered by the above-quoted part of the regulation.

The hypothetical flip-flop described above does not seem to come within the coverage of that part of the regulation because no reduction in partnership habilities took place. The regulation contemplates the reduction by the partnership of the partnership's indebtedness that was

31. See 1 A. Willis, J. Pennell \& P. Postlewaite, supra note 1 , at $\$ 46.03$.

32. Treas. Reg. § 1.752-1(b)(1) (1960) (emphasis added). 
a portion of the partner's tax basis. For example, the limited partners in the hypothetical each included $\$ 180,000$ of the partnership's $\$ 400,000$ nonrecourse inortgage note in the basis of their partnership interests. If the inortgage indebtedness was subsequently reduced by $\$ 100,000$, limited partners $A$ and $B$ would each have to reduce their basis by $\$ 45,000$; if that reduction exceeded the partner's adjusted basis, the partners would be taxed on the excess or the resulting gain. ${ }^{33}$ No such reduction in the partnership's debt has occurred, however, because the shift in profit and loss sharing has no effect on the mortgage debt. Instead, there has been merely an "internal" shift-among the partners-in the proportion of profits and losses to which each partner will be entitled in the future. The condition that is set forth in the first sentence of Treasury Regulation 1.752-1(b)(1), reduction in the debt, has not been met. Because no such reduction has taken place, the partnership owes the same amount of money that it did before the profit and loss shift; thus, the regulation arguably is mapphicable.

Subsection (b)(2) of the same regulation sets forth an alternative way in which a constructive distribution can take place: "Where a partnership assumes the separate liabilities of a partner or a liability to which property owned by such partner is subject . . . the amount of the decrease in such partner's liabilities is treated as a distribution of money by the partnership to the partner." ${ }^{34}$ As in subsection (b)(2), the language contemplates action by the partnership, in this case the partnership must assume the hability previously assumed by a partner.

One example incorporated into Treasury Regulation 1.752-1(b)(2) illustrates this point. A partner contributes property valued at $\$ 1000$ to a partnership $\mathrm{m}$ exchange for a one-third interest in the partnership. The property is subject to a mortgage of $\$ 150$, but the partner's original basis of $\$ 1000$ is reduced to $\$ 900$, because two-thirds of the $\$ 150$ mortgage liability is now allocable to the other partners. ${ }^{35}$ In the example given in the regulation, a transfer of property to the partnership and a redistribution of mortgage liability resulted in a constructive distribution to the partner of $\$ 100$. In the hypotletical, on the other liand, no transfer between a partner and the partnership took place; instead, there was only a shift in profit and loss interests among the partners themselves. Thus, in the hypothetical case, the partnership's failure to assume the partner's previous liabilities arguably prevents the regulation froin applymg.

33. See I.R.C. $\$ 731(\mathrm{a})(1)(1982)$.

34. Treas. Reg. § 1.752-1(b)(2) (1960).

35. Id. 
This analysis of both subparts of Treasury Regulation 1.752-1(b) proceeds from the premise that in each case there is an unsatisfied precondition to finding a taxable event. This attempt to prevent section 752 from applying to flip-fiops, however, is fiawed. Treasury Regulations are inerely interpretations of the Code. Although regulations inay, if left undisturbed over time, gain something akin to the force of law, ${ }^{36}$ they are in essence only "administrative interpretation[s] of the tax statute," 37 and thus cannot be viewed as definitive pronouncements on the scope of the Code. Therefore, Treasury Regulations must be viewed as exeinplary, not definitive. The regulations often list several possible fact situations to which a Code provision iniglit apply, but the regulations do not purport to exhaust the scope of the Code's application. Thus, the Code may apply to a fact situation that does not fall within the requirements of a particular regulation. Noncoverage in an illustrative context does not dictate noncoverage in the wider statutory sense. As a result, even though the regulations under section 752 do not apply, ${ }^{38}$ the reduction in a partner's sliare of partnership liabilities occasioned by a flip-fiop 39 seems to constitute a constructive distribution under section 752(b), unless soine alternative method is available for removing flip-flops froin the coverage of that section.

\section{Separation of Partnership Interests}

The arguinent that flip-flops are taxable events under section 752 necessarily assumes that when a partner reduces his profit and loss interest, his share of partnership liabilities is simultaneously reduced. As Treasury Regulation 1.752-1(e) states:

A partner's share of partnership liabilities shall be determined in accordance with his ratio for sharing losses under the partnership agreement. . . . However, where none of the partners liave any personal liability with respect to a partnership liability (as in the case of a mortgage on real estate acquired by the partnership without the assumption by the partnership or any of the partners of any liability on the mortgage), then all partners, including limited partners, shall be considered as sharing such liability under section 752 (c) in the same proportion as they sliare the profits. ${ }^{40}$

36. Treasury Regulations are entitled to substantial deference and "must be sustained unless unreasonable and plainly inconsistent with the reveuue statute." Commissioner v. South Tex. Lumber Co., 333 U.S. 496, 501 (1948); accord, United States v. Correll, 389 U.S. 299, 306-07 (1967).

37. W. ANdrews, Basic Federal Income TaXation 13 (2d ed. 1979).

38. See supra notes 25-26 and accompanying text.

39. See supra note 25.

40. Treas. Reg. § 1.752-1(e) (1960). 
The regulation indicates that a reduction in a partner's profit and loss interests inevitably results in a corresponding reduction in the partner's share of the partnership. Nevertheless, it may be argued that if the interests in a partnership are divided into several components the reduction in one component will not necessarily entail reduction in others. Unless there is a reduction or an mcrease in liabilities, section 752 does not apply. ${ }^{41}$

Partnership agreeinents frequently divide partners' interests into separate components. One colnponent is a capital interest. ${ }^{42}$ Capital interests usually consist of the right to a share of the partnership's assets upon liquidation of the partnership and are distinct from a partner's interest in profits. Therefore, although a partnership agreeinent may provide that limited partners will have the same percentage interests in capital, in profits, and in losses, those mterests need not be the saine.

Further justification for distinguishing between profit interests and capital interests is found in the Uniform Partnership Act, which states that "[t]he property rights of a partner are (1) his rights in specific partnership property, (2) his interest in tlie partnership, and (3) his riglit to participate in the inanagement."43 The second interest generally is equated with a partner's right to share in partnership profits, ${ }^{44}$ and the first interest would most likely be regarded as a capital interest. ${ }^{45}$

41. But see 1 A. Willis, J. Pennell, \& P. Postlewaite, supra note 1 , at $\S 46.02$.

42. See Treas. Reg. $\S 1.704-1(e)(1)(v)$ (1983). This regulation provides:

Capital interest in a partnership. For purposes of Section 704(e), a capital interest in a partnership means an interest in the assets of the partnership, which is distributable to the owner of the capital interest upon his withdrawal from the partnership or upon liquidation of the partnership. The mere right to participate in the earnings and profits of a partnership is not a capital interest in the partnership.

The limitation, in the introductory language of subsection (e), to family partnerships at first appears troubling. In fact, however, the Regulation is applied routimely in situations other than family partnerships, even by the Internal Revenue Service. See Technical Advice Memorandum 7707260880 A (July 29, 1977). Furthermore, other sections of the tax regulations refer to capital interests in contexts not involving family partnerships. See, e.g., Treas. Reg. § 1.707-1(b)(3) (1983) (reference to I.R.C. $\$ 267$ necessary for computing extent of partner's ownership of capital interest); Treas. Reg. $\S 1.401-10$ (d) (1983); Treas. Reg. $§ 53.4943-3$ (c)(2) (1983).

Additionally, general usage among tax practitioners indicates that the distinction between capital interests and profit interests is not confined to family partnerships. See, e.g, AMERICAN L. InSt. Federal Income TaX Project 83-84 (Tent. Draft No. 8, 1982).

43. UNIF. PARTNERShIP ACT § 24, 6 U.L.A. 324 (1969).

44. See, e.g., Luick v. Luick, 164 Pa. Super. 378, 380, 64 A.2d 860, 861 (1949) (partner's interest in partnership held to be his share of partnership profits and surplus, and to constitute personal property).

45. There is substantial authority for the proposition that individual partners have no interests in specific partnership property, and that such property belongs instead to the firm. See, e.g., Buell Cabinet Co. v. Sudduth, 608 F.2d 431, 432 (10th Cir. 1979); Wolfe v. Hewes, 41 N.C. App. 88, 91, 254 S.E.2d 204, 206 (1979). Thus, the partners' rights to specific items of property arise only upon liquidation of the partnership, when the remaining assets and capital are distributed. 
Capital accounts are the most convenient method for separating capital imterests from other imterests. Capital accounts are simply accounting balances that reflect each partner's equity investment in the partnership ${ }^{46}$ and usually begin with the original contribution of capital. They are subsequently mcreased by any additional contributions of capital, as well as by the partner's share of partnership proflts, and are decreased by distributions to the partner that reduce partnership capital, as well as by the partner's share of partnership losses. ${ }^{47}$ The Code does not require any particular method for maintaining and computing capital accounts. ${ }^{48}$ For example, to reflect tax basis more accurately, a partnership agreement could provide that partners' shares of partnership habilities will be included in computing individual capital accounts. ${ }^{49}$ Upon termination of the partnership, assets are distributed to the partners according to the balances in their capital accounts. ${ }^{50}$ Deficits must be made up by payinents from the partners, and account surpluses are distributed. Thus, a partner's capital account balance serves as a method of computing the amount owed to him upon hquidation.

A shift in profit and loss interests, such as that occurring in a flipflop, does not affect a partner's capital interest. When a capital account is calculated according to the criteria set forth above, no change will be registered when a partner's profit and loss imterests are shifted, because nothing occurs to decrease the account balance, unless the partners' shares of partnership liabilities are included in their capital accounts. A distribution to partners in reduction of partnership capital does not occur because capital is in no way affected; similarly, the shift in profits and losses does not imstantaneously reduce partnership losses already allocated to the partners. ${ }^{51}$ In the hypothetical described im section I, the limited partners will have a lower percentage of profits and losses allocated to them following the flip-flop in proflt and loss imterests. Consequently, their capital account balances will differ in future years

46. See W. McKee, W. Nelson \& R. Whitmire, supra note 12, at If 6.05[1].

47. See, id:; cf. 3 A. Willis, J. Pennell \& P. Postlewaite supra note 1, at apps. A-14 (general partnership model agreement), B-6 (limited partnership model agreement).

48. See Weidner, supra note 3, at 224.

49. See id. Weidner further points out that deduction of partnership tax losses from capital accounts means that actual economic investment is not refiected.

50. Comment, Partnership Allocations and Capital Accounts: A Technical Advice Memorandum as Administrative Minefield, 35 TAX L. REv. 441, 446 (1980).

51. In the event partnership liabilities, such as mortgage imdebtedness, are included in partners' capital accounts, Treasury Regulation $1.752-1$ (e) would seem to require a reduction im the limited partners' accounts because of the statement in that Regulation that partnership liabilities are to be shared in the same proportion as losses. See Treas. Reg. $\$ 1.752-1$ (e) (1983). 
as compared to when their profit interest was ninety percent. Thus, depending on whether the partnership registers profits or losses, partners will have to allocate more or less money to bring their capital accounts to zero upon liquidation than they would have had to when they held a larger profit interest. But the shift caused by the flip-flop does not itself alter the capital accounts, and, thus, does not directly affect any partner's rights to share in proceeds of the partnership upon liquidation. As a result, because a flip-flop does not alter partners' habilities, inasmuch as these are reflected in their capital accounts, one may argue that no taxable event occurs under section 752 .

In short, the arguinent that flip-flops involve no constructive distribution derives from the fact that partnership agreements can be drafted to distinguish between the various components of a partner's interest. When partners remain liable for partnership obligations for the duration of the partnership, an intervening flip-flop should not be viewed for tax purposes as reducing a partner's liability. As long as the partner has the same obligation upon liquidation to make up the balance in his capital account, or the saine right to distribution of partnership assets available after payment of obligations, no reduction in liability seems to have taken place. To the extent that a partner's capital interest remams constant throughout the life of the partnership, a change in the partner's profit and loss sharing will not necessarily affect a partner's rights or habilities upon hquidation. These two interests are wholly separate, and a change in one need not entail a corresponding change in the other.

Although the analysis above seems attractive, this attempt to escape the application of section 752(b) is not likely to succeed. The argument equates "liabilities" for subchapter $\mathrm{K}$ purposes with a partner's obligations upon termination of the partnership or his interest in it. Yet to equate these two things is clearly not permissible. The first part of section 752(b) does not refer to obligations or habilities of individual partners, but instead to "a partner's share of the liabilities of a partnership."52 Similarly, the opening phrase of the applicable regulation is: "[a] Partner's share of partnership liabilities." 53 There is a critical distinction between shares of partnership liabilities during the existence of a partnership, and an individual partner's capital account deficit upon termmation of the partnership. The former is a fundamental coinponent in subchapter $\mathrm{K}$ analysis of partnership incoine; the latter merely deals with accounting primciples in the organization of the particular partnership. A partnership hability, such as nnortgage indebtedness on

52. I.R.C. § 752(b) (1982).

53. Treas. Reg. $\& 1.752-1(e)(1983)$. 
the partnership's principal asset, is quite different from the deficit in a partner's capital account; and it is the former that section 752 addresses. Indeed, depending on the type of partnership, there may not be capital account deficits to reconcile. At any rate, equating partnership liabilities with a partner's obligations upon termination of the partnership refiects incorrect usage of the term "liability." Consequently, if these terms are employed correctly, Treasury Regulation 1.752-1(e) will operate to reduce a partner's share of partnership habilities-the only relevant liabilities-when there is a flip-flop that causes a decrease in profit and loss interests. Thus, distimguishing between capital interests and profit and loss sharing will not serve to prevent section 752(b) coverage of flip-flops.

\section{ECONOMIC GAIN}

One additional argument for not taxing flip-flops as constructive distributions of cash is that there is no economic gain to the limited partner. ${ }^{54}$ Absent some form of economic gam, there is nothing to be taxed. ${ }^{55}$ As one court stated, "true economic gain is the sine qua non to income under the Code and the Sixteenth Amendinent."56 Exammation of analogous situations involving release from liability provides a useful tool for analyzing partnership flip-flops. Cancellation of indebtcdness is one area around which a significant body of case law has developed.

United States v. Kirby Lumber Co. ${ }^{57}$ was the first case to establish that cancellation of indebtedness could constitute income to the debtor. ${ }^{58}$ The corporate taxpayer in that case repurchased some of its own bonds on the open market for $\$ 138,000$ less than the price at which it had issued them earlier the same year. Because the company had $\$ 138,000$ in available assets after the repurchase that were no longer offset by an obligation to pay full value for the bonds, the Supreme

54. Questions not discussed in this note may in some instances arise as to whether certain allocations have substantial economic effect. See I.R.C. \& 704(b)(2) (1982). A perceptive illustration of such questions, and a discussion of when allocations may be found to have been made merely for tax avoidance, is found in Orrisch v. Commissioner, 55 T.C. 395 (1970).

55. An exception to this principle is the situation in which some provision of the Code states that a taxable event occurs, even though no economic benefit to the taxpayer has occurred. See, e.g., I.R.C. $\S \S 1245,1250(1982)$ (recapture of depreciation). Whether $\S 752(b)$ is such a provision, at least as regards flip-flops, is the question discussed in this section.

56. Spartan Petroleum Co. v. United States, 437 F. Supp. 733, 735 (D.S.C. 1977).

57. 284 U.S. 1 (1931).

58. A useful discussion of the background litigation involved in the establishment of this principle is found in Bittker \& Thompson, Income From the Discharge of Indebtedness: The Prog. eny of United States v. Kirby Lumber Co., 66 CALIF. L. REv. 1159, 1159-61 (1978). 
Court held that the transaction generated taxable income. ${ }^{59}$ The Kirby Lumber rule does not, however, mean that every case of cancellation of indebtedness gives rise to realization of income. For example, if the taxpayer is unable to derive any economic benefit from the cancellation, perhaps because of bankruptcy, courts will hold that no taxable income has been received. E.B. Higley \& Co. v. Commissioner, ${ }^{60}$ a Board of Tax Appeals case decided shortly after Kirby Lumber, involved a corporate taxpayer that was in the hands of a receiver. Because the corporation was insolvent, its creditors agreed to cancel its debt so that it might reorganize and continue as a viable business. The Board held that because the corporation was insolvent when the creditors cancelled the debt, the corporation had not received any taxable income. Critical to this conclusion was the finding that " $[t]$ he parties contemplated no profit from the transaction, which merely relieved the taxpayer from a portion of its liability." 61 The Board considered the Kirby Lumber decision, but found it inapplicable because it beheved that certain extenuating factors-here, insolvency-could prevent a reduction in liability from triggering a taxable event. ${ }^{62}$

With this background in mind, one might argue that flip-flops present an even stronger case for not allowing imposition of tax liability than cancellation of indebtedness in bankruptcy proceedings. In Higley, cancellation of the taxpayer's debt at least meant that the company would not be called upon in the future to pay the money it owed to creditors; in that sense one can detect an indirect economic benefit. But a partner whose profit interest changes does not even realize this attenuated form of benefit. No debt is cancelled upon the shift in his profit interest, nor does he obtain any release from his share of habilities. Without some such benefit, the underlying principle of Higley seems to indicate that flip-fiops may not be taxable events.

Similarly, in Towers \& Sullivan Manufacturing Co. v. Commissioner, 63 a case involving a taxpayer corporation in debt to several creditors, the creditors forgave twenty-five percent of the taxpayer's debt and the taxpayer contested the Commissioner's finding that the forgiven debt constituted taxable income. The Board of Tax Appeals held that there was no income because even after subtracting the taxpayer's income from the amount forgiven, the company still sustained a net loss for the year. Under these circumstances, the Board noted, "we do
59. 284 U.S. at 3.
60. 25 B.T.A. 127 (1932).
61. Id. (emphasis added).
62. Id. at 127-28.
63. 25 B.T.A. 922 (1932). 
not see how the amount forgiven can constitute imcome, but there is ' $a$ inere diminution of a loss." "64 The Board found insufficient proof of incoine despite the fact that the cancellation enabled the taxpayer to continue its business, and to make a profit in subsequent years. ${ }^{65}$ Nothing in the Code limits the Towers \& Sullivan principle to cases of forgiveness of debt; ${ }^{66}$ indeed, this is but one of several forms of possible

64. Id. at 925 .

65. One criticism that might be leveled at Towers \& Sullivan is its reliance on two prior cases: In re Meyer Jewelry Co., 3 B.T.A. 1319 (1926) and John F. Campbell Co. v. Commissioner, 15 B.T.A. 458, affd sub nom. Burnet v. John F. Campbell Co., 50 F.2d 487 (D.C. Cir. 1931). These are also cases in which forgiveness of debt was held not to constitute income; the problem is that there is authority to the effect that Kirby Lumber overruled both of these cases. See Lakeland Grocery Co. v. Commissioner, 36 B.T.A. 289, 293 (1937) (Sternhagen, J., concurring) ("Both Meyer Jewelry Co. . . . and Burnet v. Campbell Co. . . . were decided before United States v. Kirby Lumber Co., and in my opinion are mcompatible with that decision and were overruled by it."). Judge Sternhagen's statement need not be seen as troublesome for three reasons. First, the decision in Meyer Jewelry Co. that there was no taxable income was based in part on the then-applicable definition of imcome as "gain derived from capital, from labor, or from both combined." See Stratton's Independence, Ltd. v. Howbert, 231 U.S. 399, 415 (1913). To the extent that Kirby Lumber overruled Meyer Jewelry Co., the invahdity of the latter case should be rcgarded as due to the now-superseded definition of income applied there. The result in Towers \& Sullivan did not depend on that outmoded definition of income, and thus rests on an independent basis. That basis, the theory of economic gain, is consistent with Kirby Lumber, indicating that the argunent in Towers \& Sullivan is still valid.

Second, Higley, decided the same year as Towers \& Sullivan, reached the same result-that cancellation of indebtedness does not constitute income to an insolvent debtor. Higley relied on the theory that a mere reduction in liability could not be equated with taxable income-which is just an instance of the principle that economic gain is a prerequisite to taxation. Higley explicitly considered the recent decision in Kirby Lumber, and found it mapphicable to cases im which a debtor's insolvency prevented economic benefit.

Third, unany cases decided after Kirby Lumber have followed the economic gain theoryindicatimg that the two early cases should not be regarded as having been overruled by Kirby Lumber. See infra note 68 and accompanymg text. As a result, Towers \& Sullivan, and related cases, should not be seen as inconsistent with Kirby Lumber; the latter was sinuply a case where economic gain accrued to the taxpayer, making the forgiveness of debt an appropriate event to $\operatorname{tax}$.

66. Another area in which courts loold that taxation is inappropriate in the absence of proof of economic gain is the granting of corporate credit to shareholders. Generally, courts refuse to allow imposition of tax liability until some actual release of the shareholder froin liability has occurred, or some other forn of gam accrues to the taxpayer. A case in point is Maher v. Commissioner, 469 F.2d 225 (8th Cir. 1972), in which the taxpayer purchased all of the outstanding stock of four corporations, Inaking payment in part by promissory notes. As part of a plan to combine the operations of two of the companies, the taxpayer assigned his contractual interest in the stock of one corporation in exchange for the corporation's assumption of his liability on the promissory notes. That company was subsequently dissolved, and its assets transferred to the taxpayer, but only after it had inade substantial paynents of principal and interest on the two notes. The corporation deducted these payments on its tax return in the appropriate years. The question arose whether the taxpayer could be held to have realized incoine (to the extent of the assumimg corporation's earned surplus) in the amount of the payments inade on the notes, in the year the corporation assumed the taxpayer's liability on the notes, or in the year the payments actually were inade. The United States Court of Appeals for the Eighth Circuit reversed the Tax Court's determination that the taxpayer reccived taxable income in the former year on the theory 
income set forth in section 61(e). Instead, as stated in Spartan Petroleum Co. v. United States, ${ }^{67}$ the requirement of economic benefit as a prerequisite to taxation is applicable to other inetlods by which income is recognized. ${ }^{68}$ Cancellation of debt, therefore, is but one of several

that there was no release from liability, and thus no economic benefit to the taxpayer untl the corporation made the payments.

[T]he general rule is that there is no income unless and until there lias been a release of hability. . . In the present case, while [the assuming company] contractually assumed primary liability on the two notes, taxpayer remaimed secondarily liable until the notes were actually paid. Whatever "economic benefit" may liave accrued to taxpayer from the reduction of his liability . . . is clearly mcapable of being evaluated on an objective basis.

469 F.2d at 229. See also Vinnell v. Commissioner, 52 T.C. 934 (1969); Kleedon v. Commissioner, 3 T.C.M. (CCH) 1123 (1944); $C f$. Jachs v. Commissioner, 277 F.2d 879, 882-83 (8th Cir. 1960) (existence of constructive dividend from corporation to slrareholder dependent not upon motive or interest of corporation, but upon receipt of economic benefit); Wall v. United States, 164 F.2d 462 (4th Cir. 1947); Schalk Chem. Co. v. Commissioner, 32 T.C. 879 (1959), aff d, 371 F.2d 816 (1st Cir. 1967) (taxpayer who is a recipient of some form of credit from a corporation receives income im the year the corporation lias the financial capacity to pay the debt and the sliareholder lias the power to cause the debt to be paid); Treas. Reg. $\$ 1.451-2$ (a) (1983) (constructive income deemed received in year made available for use, provided taxpayer's control of receipt is not subject to substantial restrictions or limitations).

67. 437 F. Supp. 733, 735 (D.S.C. 1977).

68. Sheraton Plaza Co. v. Cominissioner, 39 T.C. 697 (1963), is an example of a subsequent case following the principle that economic gain is a necessary prerequisite to taxation. The taxpayer corporation was a wholly-owned subsidiary of a trust. After several years of operation the trust purchased all the outstanding capital stock of the operating company that managed the taxpayer's hotel busimess. The trustees then adopted a reorganization plan whereby the operating company assigned all of its casle, accounts, imventory, and other assets to the taxpayer, in exchange for 750 shares of the taxpayer's stock and an agreement by the taxpayer to assume all the operating company's debt. Thereafter, the taxpayer claimed deductions for rent payable to the trust under various lease agreeinents. Because of concern over the federal imcome tax effect of inclusion of both the trust and the taxpayer on the parent company's consolidated tax return, the trust cancelled a debt of $\$ 72,000$, owed by the taxpayer by virtue of liability originally incurred by the operating coinpany. The Commissioner assessed a deficiency in the amount of the cancellation, but the Tax Court held to the contrary. The court stressed the importance of viewing the entire transaction as a whole; here, the taxpayer without additional consideration assumed the obligation to pay its parent the money owed by a third party, and it was this debt that was cancelled. The significant factor is that at that time there was no more than an arms-length relationship between the tenant and the petitioner's parent, the landlord, whicl actually received none of the accrued rent; and one can safely assume, since no effort was made to collect the arrearages, that the original debtor was insolvent. 39 T.C. at 705. The court here stressed the fact that no economic benefit was conferred. Instead, it viewed the cancellation as a contribution to capital by the taxpayer's sole shareholder, because the cancellation was part of a transaction that involved the transfer of property.

In Astoria Marme Construction Co. v. Commissioner, 12 T.C. 798 (1949), the taxpayer corporation borrowed money for merchandise used in its busmess, whicl it was later unable to repay. Because the creditor felt he could collect no more than $\$ 500$, lie accepted that amount in satisfaction of the outstanding debt of $\$ 26,000$. The Commissioner contended that the amount cancelled should be included in the taxpayer's income, but the court noted that the taxpayer's outstanding obligations exceeded its book value, and thus it was insolvent. Therefore, mcome could be recognized only to the extent that cancellation of the debt resulted in an excess in value of assets over reinaming obligations. Assessing the sums listed in the taxpayer's accounts likely to be collected, 
ways in which one's liabilities may be reduced. Whatever the method of reduction, if no economic gain is derived, taxation is inappropriate. In the case of flip-flops, one would argue that because there is not even a transaction giving rise to a reduction of liability, the flip-flop does not generate any economic gain for partners. Whatever effect the shift im profit and loss sharing may have on future imcome, it in no way affects liabilities of the partnership, or a partner's eventual right to proceeds on liquidation.

Nevertlieless, this argument, like tlose preceding it, is flawed. First, to the extent that the argument depends on the premise that there is no reduction in liability when a flip-flop occurs, it rests on an imcorrect assumption that a partner's share of partnership liabilities can be equated witl a partner's obligations upon termination of the partnership. ${ }^{69}$ Regardless of the effect on capital account balances, the important liabilities for subchapter $\mathrm{K}$ purposes are those of the partnership; according to Treasury Regulation 1.752-1(e), one's share of those liabilities must be reduced if one's share of profits and losses is reduced.

Second, the policy underlying the argument-that insolvency and similar situations are a poor time to assess taxes-simply has no applicability to real estate limited partnerships which high-bracket taxpayers frequently use as investments. An individual whose busmess has collapsed because of bankruptcy is in a vastly different position than one whose tax bracket permits limi to make profitable use of partnershipgenerated deductions; the former certainly is more deserving of solicitous tax treatinent than is the latter.

Tle third, and perhaps most important problem with this argument results froin the language of the statute. Section $752(\mathrm{~b})$, in fairly

the Tax Court found the total value of assets after discharge of the $\$ 26,000$ would probably not exceed $\$ 11,000$. Thus, the court held that the Commissioner had erred in including $\$ 25,500$ in the taxpayer's income.

Astoria Marine simply applied a rule that found its basis in a 1937 Board of Tax Appeals case, Lakeland Grocery Co. v. Commissioner, 36 B.T.A. 289 (1937). The insolvent taxpayer corporation there entered into an agreement with its creditors whereby the latter accepted $\$ 15,000$ in satisfaction of the former's $\$ 105,000$ debt. The effect was to leave the company with a positive net worth of $\$ 40,000$. The court held there was taxable income, but only to the extent the debtor became solvent. Debt cancellation does not result in income if the taxpayer was insolvent before, and remains so after, the discharge, because there is no increase in the taxpayer's net worth by reason of such a discharge. That is, no gain is realized. See also Progress Paper Co. v. Commissioner, 20 B.T.A. 234 (1930); Eastside Mfg. Co. v. Commissioner, 18 B.T.A. 461 (1930); Simmons Gin Co. v. Commissioner, 16 B.T.A. 793 (1929), affd, 43 F.2d 327 (10th Cir. 1930). Likewise, in White v. Commissioner, 34 B.T.A. 424 (1936), a portion of a partnership's debt was cancelled. Because the partnership was solvent and able to pay its debts in the year of cancellation, it was held to have received income to the extent it was made solvent.

69. See supra text accompanying notes 52-53. 
unequivocal terms, equates reductions in shares of partnership habilities with distributions of incorne. That fact seems to put section 752 on the same footing as such other provisions as section 1245 and section 1250,70 which create a taxable event in situations in which no custornary form of incoine exists. Thus, the mandate of section 752(b) seeins to dispel any doubt about the tax consequences of flip-flops. ${ }^{71}$

\section{CONCLUSION}

This note has developed three possible reasons why section 752 might not apply to flip-flops. Each approach appears unsatisfactory. The first approach will not succeed because requirements set forth in the applicable Treasury Regulations that would assist partners in escaping the terms of section 752 cannot be deemed to control the scope of the tax statute; instead, the fact situations covered by the regulations are merely exemplary, not definitive. The second approach fails because separation of capital interests and profit and loss sharing does not provide a distinction ineaningful for subchapter $\mathrm{K}$ analysis; the obligations relevant for capital accounts are not the same as the liabilities that are the subject of section 752 , and to the extent the latter are altered by flip-fiops, the Code indicates that taxation inust follow. The third approach, analogizing flip-flops to cancellation of indebtedness and other situations in which tax will be deferred or forgiven, is also inappropriate; high-bracket taxpayers do recognize substantial benefit froin linited partnerships, and should not escape tax liability triggered by a shift in profit and loss interests contrary to the mandate of section 752.

Ross Lipman

70. See supra note 55 .

71. The current Code treatment of discharge of debt in cases of bankruptcy or insolvency illustrates this point. I.R.C. \& 108(b)(2) directs that a taxpayer's tax attributes, such as basis of various properties, be reduced when a discharge is excludible from gross income. Reduction of these attributes is just a reflection of the fact that if a taxpayer receives some reduction of his habihties, even where no current economic gain results, his tax burden in the future should reflect the benefit received. Thus, the former complete forgiveness of tax that resulted froin cases holding that no taxable event occurred has been eliminated. Instead, $\S 108$ simply allows a deferral of tax-for example, until the time of sale of property the basis of which was reduced pursuant to $\S 108$. 